\title{
PEAK EXPIRATION FLOW PREDICTION VALUE IN THE ELDERLY WITH THE TAI CHI TRAINING \\ Theresia A Hanitami ${ }^{1)}$, Prettysun A Mellow ${ }^{2)}$, Inge Wattimena ${ }^{3)}$
}

\begin{abstract}
Introduction: With increasing age, the elderly is more vulnerable to various physical disorders. One of them is a decrease in respiratory system function due to decreased respiratory muscle mass. Tai Chi training can be used as a health facility to maintain an excellent respiratory system.

Purpose: Find out the difference between peak expiration flow prediction values in the elderly who do and do not participate in Tai Chi training.

Method: This research used an observational analytic method with a cross-sectional design and used purposive sampling technique. The sample of this research was the elderly aged 6075 years who meet the inclusion criteria. APE measurements were carried out three times, and the highest value was taken. Data were analyzed using the Mann-Whitney test with a computer program.

Results: The data showed that APE value in the elderly who participated in Tai Chi training was $319.3 \pm 91.42$ while the elderly who did not take Tai Chi training was $265.6 \pm 67.04$. Statistical test results showed significant difference.

Conclusion: Based on Mann Whitney's statistical calculations, it can be seen that the significance value or $p$-value is $0.036<0.05$. It means that there is a significant difference in the average predicted value of peak expiratory flow between elderly who take Tai Chi training with elderly who do not take Tai Chi training, where APE in the elderly who practice Tai Chi is greater than the elderly who do not practice Tai Chi.
\end{abstract}

Keywords: Elderly Practice Tai Chi, APE Prediction Value

\footnotetext{
${ }^{1)}$ Student of Faculty of Medicine, Widya Mandala Catholic University Surabaya, Jl. Kalisari Selatan No.1 Surabaya Email: theresiaarumnia@gmail.com

${ }^{2)}$ Internal Medicine Department, Faculty of Medicine, Widya Mandala Catholic University Surabaya, Jl. Kalisari Selatan No. 1 Surabaya

${ }^{3)}$ Public Health Department, Faculty of Medicine, Widya Mandala Catholic University Surabaya, Jl. Kalisari Selatan No. 1 Surabaya
} 


\section{INTRODUCTION}

Aging is a process of slowly degrading ability foe networks to repair / replace itself and maintain its typical structure and function so that it cannot withstand injury (including infection) and repair the damage suffered ${ }^{1}$. Based on population projection data, it is estimated that in 2017 there will be 23.66 million older people in Indonesia $(9.03 \%)^{2}$.

Decreased respiratory function is one of the complaints experienced by the elderly. Decreased muscle mass affects respiratory muscles so that the respiratory system begins to decline. It causes decreased lung elasticity, stiffness of the chest wall, and decreased chest muscle strength. All of them have consequences in decreasing the ventilation-perfusion ratio in the part of the lung that is not free, and the widening of the arterial alveolar gradient to oxygen ${ }^{1}$.

Research conducted by Sharma and Goodwin ${ }^{3}$, states that a decrease in respiratory function in terms of FEV1 value has a significant relationship with age. The average reduction in FEV1 is 25$30 \mathrm{ml} /$ year starting from the age of 35 to 40 years old, and it can increase to 60 $\mathrm{ml} /$ year at the age of 70 years old.

According to Roman and Rossiter ${ }^{4}$, aging is related to decreased physical activity. This finding is due to decreased age-related respiratory function, which causes a decrease in lung elasticity, thereby causing active elderly to have limited ventilation in exercising. A simple way to determine someone's respiratory function is to measure Peak Expiration Flow (APE). APE speed is the highest flow that can be reached during maximum expiration. The value obtained at APE depends on the airway diameter, age, gender, height, and it must be adjusted to the normal values table. In the elderly, APE value tends to be lower ${ }^{5}$. Therefore, regular breathing practice is needed to improve respiratory functions.

One of the sports activities in society is Tai Chi training. According to $\mathrm{Chan}^{6}$, a 3-month Tai Chi program in PPOK patients showed efficacy. After doing the Tai Chi training, it was found that the elderly who take Tai Chi showed improved lung function. The enhancement of lung function, such as, Forced Vital Capacity (FVC) or forced vital capacity and Forced Expiratory Volume in One Second (FEV1). The increase occurred as much as $18 \%-19 \%$.

early survey results that was conducted on 9 February 2019 in the Central Park group of Tai Chi training, found 25 elderly with an age range of 6080 years. From interviews with elderly members of Tai Chi training, they have been doing Tai Chi training for about five 
years. From Tai Chi training, they experience benefits such as relieving body aches, relieving stress, and increasing muscle strength. The survey results conducted in different places on 11 February 2019 at Bhaskara Jaya Integrated Healthcare Center; there are 40 elderly with an age range of 50-75 years.

\section{METHOD}

This research was an observational study (non-experimental) with cross-sectional study design. The populations in this research were the elderly group doing Tai Chi training with the elderly group who had never participated in Tai Chi training. The subject in this study was the elderly group who did Tai Chi training as the Central Park Tai Chi member in Surabaya. The second elderly group is the people who never participated in Tai Chi training. Both groups are involved in the Bhaskara Jaya Integrated Healthcare Center Surabaya for the inclusion and exclusion criteria, respectively.

The sampling technique used nonprobability sampling, namely, purposive sampling. In purposive sampling, we chose subjects that fulfill the inclusion and exclusion criteria. In this research, the inclusion criteria are (1) age range 60 - 75 years, willing to become respondents, and signed informed consent. (2) falls into the normal - overweight category. (3) have participated in Tai Chi training for at least one year with regularity in the past month at least 2-3 times a week. (4) For the elderly who do not participate in Tai Chi training, they did not do regular sports activities or did not do routine activities that could significantly improve the ability of respiratory function (example: cycling for work). Exclusion criteria set in this research were:

For elderly who participated and did not participate in Tai Chi training smoking history, coughing or shortness of breath, in interviews suffering from a lung disease that causes airway obstruction (Asthma, PPOK, lymph node, or neoplasm in the respiratory tract), and did not suffer from spinal abnormalities (scoliosis, kyphosis, lordosis).

\section{RESULTS}

Table 1. Distribution of Research

\begin{tabular}{|c|c|c|c|c|c|c|}
\hline \multicolumn{2}{|c|}{ Subject } & \multicolumn{2}{|c|}{ Based } & \multicolumn{2}{|c|}{ on } & Age \\
\hline & & & \multicolumn{4}{|c|}{ Elderly } \\
\hline & & & \multicolumn{2}{|c|}{ Tai Chi Training } & \multicolumn{2}{|c|}{ Don't Tai Chi Training } \\
\hline & & & Female & Male & Female & Male \\
\hline Age & $60-65$ & Count & 11 & 1 & 5 & 3 \\
\hline \multirow[t]{5}{*}{ Category } & $\begin{array}{l}\text { years } \\
\text { old }\end{array}$ & $\%$ of Total & $42.3 \%$ & $25 \%$ & $22.7 \%$ & $37.5 \%$ \\
\hline & 66-70 & Count & 4 & 1 & 7 & 4 \\
\hline & $\begin{array}{c}\text { years } \\
\text { old }\end{array}$ & $\%$ of Total & $15.4 \%$ & $25 \%$ & $31.8 \%$ & $50 \%$ \\
\hline & $71-75$ & Count & 11 & 2 & 10 & 1 \\
\hline & $\begin{array}{c}\text { years } \\
\text { old }\end{array}$ & $\%$ of Total & $42.3 \%$ & $50 \%$ & $45.5 \%$ & $12.5 \%$ \\
\hline \multirow{2}{*}{\multicolumn{2}{|c|}{ Total }} & Count & 26 & 4 & 22 & 8 \\
\hline & & $\%$ of Total & $100 \%$ & $100 \%$ & $100 \%$ & $100 \%$ \\
\hline
\end{tabular}

Table 1 shows distribution of the study subjects based on age in the elderly who did and did not participate Tai Chi training. 
Table 2. Distribution of Research Subject APE Values Based on Age

\begin{tabular}{|c|c|c|c|c|c|}
\hline & & \multicolumn{4}{|c|}{ Elderly } \\
\hline & & \multicolumn{2}{|c|}{$\begin{array}{l}\text { Tai Chi Training } \\
\text { Average } \pm \text { SB }\end{array}$} & \multicolumn{2}{|c|}{$\begin{array}{l}\text { Don’t Tai Chi Training } \\
\text { Average } \pm \text { SB }\end{array}$} \\
\hline & & Female & Male & Female & Male \\
\hline \multirow[t]{3}{*}{$\begin{array}{l}\text { Age } \\
\text { Category }\end{array}$} & $\begin{array}{l}60-65 \text { years } \\
\text { old }\end{array}$ & $289.09 \pm 58.21$ & 550.00 & $246.00 \pm 55.04$ & $306.66+75.05$ \\
\hline & $\begin{array}{l}66-70 \text { years } \\
\text { old }\end{array}$ & $257.50 \pm 39.47$ & 550.00 & $238.57 \pm 43.36$ & $360.00 \pm 63.77$ \\
\hline & $\begin{array}{l}71-75 \text { years } \\
\text { old }\end{array}$ & $302.72 \pm 52.74$ & $495.00 \pm 7.07$ & $250.00 \pm 57.92$ & 210 \\
\hline
\end{tabular}

Table 2 shows distribution of the APE values of research subjects based on age in the elderly who did and did not participate in the Tai Chi exercise

Table 3. Distribution of Research Subject Based on Gender

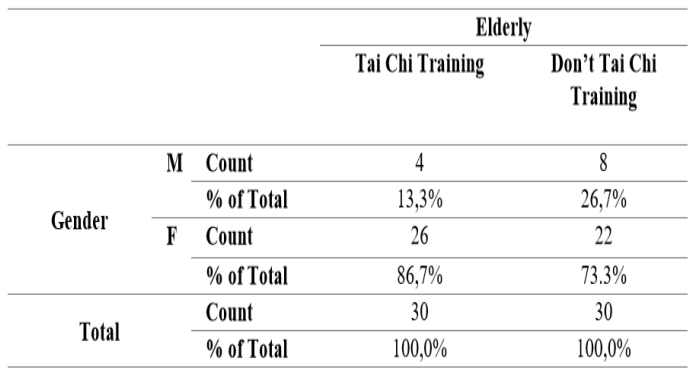

Table 3 shows distribution of the study subjects by sex in the elderly who did and did not participate in the Tai Chi exercise.

Table 4. Distribution of Research Subject APE Values Based on Gender

\begin{tabular}{cccc}
\hline \multirow{4}{*}{ Gender } & \multicolumn{2}{c}{ Lansia } \\
\cline { 3 - 4 } & $\begin{array}{c}\text { Tai Chi Training } \\
\text { Average } \pm \text { SB }\end{array}$ & $\begin{array}{c}\text { Don’t Tai Chi Training } \\
\text { Average } \pm \text { SB }\end{array}$ \\
\cline { 2 - 4 } & Male & $510.00 \pm 27.08$ & $321.25 \pm 77.90$ \\
\hline \multirow{3}{*}{ Female } & $290.00 \pm 53.81$ & $245.45 \pm 50.77$ \\
& & \\
\hline
\end{tabular}

Table 4 shows distribution of study subject APE scores based on gender of the elderly who did and did not participate Tai Chi training.

Table 5. Distribution of Research Subject Based on the Frequency of Tai Chi Training in a Month

\begin{tabular}{|c|c|c|c|c|}
\hline & & & \multicolumn{2}{|c|}{ Tai Chi Training } \\
\hline & & & Female & Male \\
\hline \multirow{8}{*}{$\begin{array}{l}\text { Tai Chi } \\
\text { Frequency }\end{array}$} & \multirow{2}{*}{12} & Count & 2 & - \\
\hline & & $\%$ of Total & $7.7 \%$ & - \\
\hline & \multirow{2}{*}{16} & Count & 12 & 3 \\
\hline & & $\%$ of Total & $46.2 \%$ & $75 \%$ \\
\hline & \multirow{2}{*}{20} & Count & 2 & - \\
\hline & & \% of Total & $7.7 \%$ & - \\
\hline & \multirow{2}{*}{24} & Count & 10 & 1 \\
\hline & & $\%$ of Total & $38.5 \%$ & $25 \%$ \\
\hline \multirow{2}{*}{\multicolumn{2}{|c|}{ Total }} & Count & 26 & 4 \\
\hline & & $\%$ of Total & $100 \%$ & $100 \%$ \\
\hline
\end{tabular}

Table 5 shows the distribution of the research subject based on the frequency of Tai Chi exercises in a month in the elderly who did and did not participate Tai Chi exercises.

Table 6. Distribution of Research Subject APE Values Based on Tai Chi Training Frequency in a Month

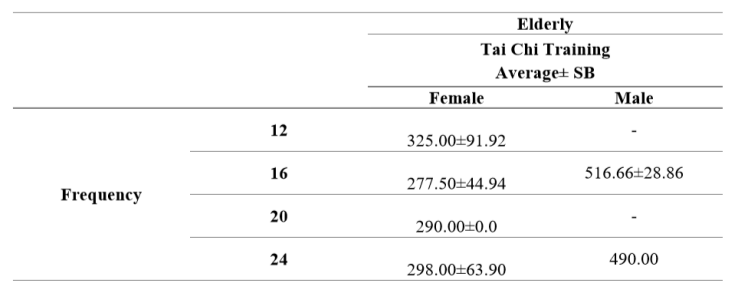

Table 6 shows the distribution of the APE values of the study subjects based on the frequency of Tai Chi exercises in a month in the elderly who did and did not participate Tai Chi exercises.

Table 7. Distribution of Research Subject APE Values Based on Tai Chi Training Duration in a Year

\begin{tabular}{cccc}
\hline & & \multicolumn{2}{c}{ Elderly } \\
\cline { 3 - 4 } & & Female & Male \\
\hline Long & $\mathbf{1 - 1 0}$ Years old & $298.33 \pm 65.20$ & 500.00 \\
\cline { 2 - 4 } time & $\mathbf{1 1 - 2 0}$ Years old & $284.54 \pm 45.90$ & $525.00 \pm 35.35$ \\
\hline
\end{tabular}


Table 7 shows the distributionof the APE value of research subjects for years of Tai Chi practice in the elderly who did and did not participate in the Tai Chi exercise.

Table 8. Analysis between the Peak Expiration Flow Prediction Value in the Elderly Who Take and Do not Take Tai Chi Training

\begin{tabular}{|l|r|}
\hline \multicolumn{2}{|c|}{ Test Statistics $^{\mathbf{a}}$} \\
\hline & \multicolumn{1}{|c|}{ Nilai } \\
\hline Mann-Whitney U & 308,500 \\
\hline Wilcoxon W & 773,500 \\
\hline Z & $-2,098$ \\
\hline Asymp. Sig. (2-tailed) &, 036 \\
\hline a. Grouping Variable: Lansia \\
\hline
\end{tabular}

Table 8 shows an analysis of the differences in the predicted values of peak expiratory flow in the elderly who did or did not participate in the Tai Chi training.

\section{DISCUSSION}

From the results of this research, hypothesis test using Mann Whitney test showed a significant $p$-value of 0.036 $<0.05$, it means that there is significant difference in the average of peak expiration flow prediction value in the elderly who did or did not participate in the Tai Chi training. It can be concluded that APE in the elderly who practice Tai Chi is higher than the elderly who do not practice Tai Chi.

The research results conducted by Puspita Adhi also showed that women aged 50 years old and over who did the Tai Chi training showed an APE value higher than those who did not practice Tai Chi ${ }^{7}$. The results obtained in this research are also consistent with the research results conducted by Yu-Feng and others. It showed a significant improvement in lung function in the group of children who participated in the Tai Chi program compared to the control group ${ }^{8}$.

As explained in theory, regular exercise or physical training aims to make muscles stronger, muscle function improvements include breathing muscles. While we are exercising or in physical training, there is a collaboration of various body muscles that are marked by muscle strength and muscle flexibility so that muscles become stronger, including respiratory muscles. Respiratory muscles play its role as the main inspiration muscles, namely: musculus intercostalis externa, musculus parasternal, diaphragmatic muscles, and additional inspiratory muscles, namely: musculus sterno cleido mastoideus, musculus scalenus anterior, musculus sacalenus medius, musculus scalenus posterior. Expiratory muscles are musculus intercostalis internus ${ }^{9,10}$.

Lung physiology and exercise have a reciprocal relationship. When pulmonary physiological disorders occur, it will affect exercise ability. Otherwise, doing regular 
dexercise can improve lung physiology. Because exercise will increase endurance and strength of the respiratory muscles, thereby increasing the ability to expand the lungs to overcome respiratory airflow resistance so that air volume will increase 9,11

As explained in theory, Tai Chi training is a martial art from China that is performed like a slow dance to evoke relaxation to the body and mind. Tai Chi training principle is a calm, peaceful heart and mind concentration. Such training principles allow nerve center to rest, improve the ability to coordinate functions of various organs, relax the whole body, and achieve deep and natural breathing ${ }^{12}$.

Every Tai Chi movement is harmonized with commands of mind and harmonized with breathing. Let them all breathe without any effort to adjust rhythmor hold it. When the breath runs naturally, it will gradually become in tune with movement. Because all Tai Chi's movements are slow, relaxed, and continuous, the breath rhythm and mind are strictly related to and out of breath. Pulling and breathing out through the nose, let the air filtered perfectly by nose hairs. In this way, eventually, slowness of motion will be related to breathing. Exhaling air movement slowly from lungs that alternate with air entry when inhaling practice the efficiency and breathing frequency, thereby increasing lung capacity, muscles stretching involved in breathing, and releasing tension. It can increase lung capacity and stretch respiratory muscles, indirectly improving lung function ${ }^{12}$. Tai Chi training are also focused on breathing abdominal movements, such as diaphragm movements and abdominal muscles, that will stimulate internal organs when internal organs are pressed with the diaphragm and abdominal muscles. Blood containing $\mathrm{O} 2$ will be delivered to every corner of the body ${ }^{13}$.

\section{CONCLUSION}

There is a significant difference in the predicted value of peak expiratory flow in the elderly who follow and do not follow Tai Chi training. The elderly group who took Tai Chi training for at least one year with regularity in the last month, at least 2-3 times a week, had higher APE value than the elderly who did not take Tai Chi training. Because the smooth and gentle movements of Tai Chi exercises are suitable for the physical condition of the elderly, it can be considered for the elderly to apply Tai Chi exercises as a means of health to improve the functioning of the respiratory system.

\section{Acknowledgement}

Author thanks: 
1. Central Park Tai Chi Training Center.

2. Bhaskara Jaya Integrated Health Center.

3. Friends of the Faculty of Medicine, Widya Mandala Catholic University of Surabaya, class of 2016.

\section{REFERENCES}

1. Martono HH, Pranaka K. Buku Ajar Geriatri: Ilmu Kesehatan Lanjut Usia. Edisi 5. Jakarta: Badan Penerbit Fakultas Kedokteran Universitas Indonesia; 2015. 515$520 \mathrm{p}$.

2. Olah raga dan manfaat bagi kesehatan. Kementrian Kesehat Republik Indones [Internet]. 2019;2-3. Available from: http://www.depkes.go.id/developme nt/site/depkes/pdf.php?id=116122300002

3. Sharma G, Goodwin J. Effect of aging on respiratory system physiology and immunology. J Cinical Interv Aging [Internet]. 2006;1:No.3: 253-260. Available from:

https://www.ncbi.nlm.nih.gov/pmc/ articles/PMC2695176/

4. Roman MA, Rossiter HB. Exercise , ageing and the lung. 2016;(7):147186. Available from: http://dx.doi.org/10.1183/13993003. 00347-2016

5. Analisis Lansia di Indonesia. Kementrian Kesehat RI [Internet]. 2017;1-2. Available from: http://www.depkes.go.id/download. php?file=download/pusdatin/lainlain/Analisis Lansia Indonesia 2017.pdf

6. Lan C, Chen S, Lai J, Wong AM. Tai Chi Chuan in Medicine and
Health Promotion. Hindawi Publ Corp [Internet]. 2013; Available from:

http://dx.doi.org/10.1155/2013/5021 31

7. Adhi PP. Pengaruh Latihan Senam Tai Chi Terhadap Arus Puncak Ekspirasi Pada Wanita Usia 50 Tahun Ke Atas [Internet]. Universitas Diponegoro; 2011. Available from: http://eprints.undip.ac.id/37094/1/P uspita Adhi.pdf

8. Chang Y, Yang Y, Chen C, Chiang B. Tai Chi Chuan training improves the pulmonary function of asthmatic children. J Microbiol Immunol Infect. 2008;88-95.

9. Guyton A, Hall JE. Buku Ajar Fisiologi Kedokteran. 12th ed. Jakarta: EGC; 2016. 460-470 p.

10. Yunus F. Aplikasi Klinik Pada Volume Paru. PIPIKRA (Pertemuan Ilm Pulmonologi dan Kedokt Respirasi) Work Faal Paru. 2003;10-5.

11. Yunus F. Faal Paru dan Olahraga. J Respirologi Indones. 1997;17.

12. Sugiarto, Marentek AE, Siswantoro H. Tai Chi Chuan. Jakarta: PT Gramedia Pustaka Utama; 2000. 27$35 \mathrm{p}$.

13. Wang C, Jean PC JL. The Effect of Tai Chi on Health Outcomes inPatients With Chronic Conditions. 2004; Available from: www.archinternmed.com 